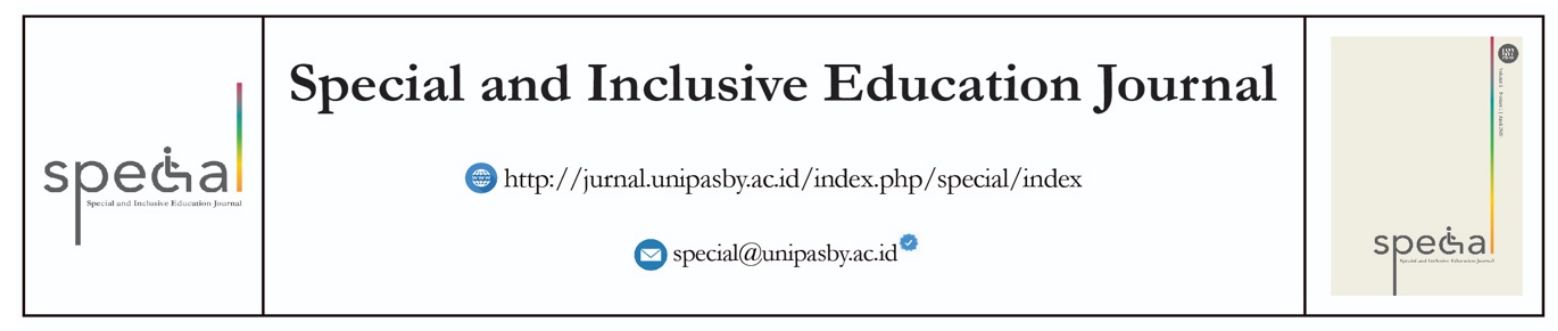

\title{
Studi Deskripsi : Perekonomian Orangtua Anak Berkebutuhan Khusus Terhadap Pendidikan Anak Berkebutuhan Khusus
}

\author{
Miftakhul Jannah \\ miftakhuljannah13091989@gmail.com
}

Mahasiswa Program Studi Pendidikan Khusus - Universitas PGRI Adi Buana Surabaya

Dukuh Menanggal XII, Surabaya 60234 Jawa Timur, Indonesia

\begin{tabular}{l}
\hline Artikel Info \\
\hline $\begin{array}{l}\text { Koresponden penulis : } \\
\text { Miftakhul Jannah } \\
\text { miftakhuliannah13091989@gmail.com }\end{array}$ \\
- Diterima 15 Maret 2020 \\
- Direview 16 Maret 2020 \\
- Disetujui 3 April 2020 \\
- Dipublikasi 29 April 2020 \\
Kata Kunci: \\
Anak Berkebutuhan Khusu, \\
Perekonomian Otangtua, \\
Sekolah Luar Biasa \\
\hline
\end{tabular}

Keywords:

Children With Special Needs, Parent's, Special School

\begin{abstract}
Absstrak
Perekonomian orangtua anak berkebutuhan khusus menengah ke bawah mengalami kesulitan pada kehidupan rumah tangga orangtua anak berkebutuhan khusus, maka akan terimbas kepada anak mereka. Salah satu aspek kebutuhan anak yang terimbas dan terlihat jelas adalah aspek pendidikan anak terutama bagi pendidikan anak berkebutuhan khusus. Penelitian ini bertujuan untuk mengetahui pengaruh ekonomi orangtua anak berkebutuhan khusus menengah ke bawah terhadap pendidikan anak berkebutuhan khusus Metodologi yang digunakan adalah penelitian Kualitatif dengan subyek penelitian ini adalah orangtua anak berkebutuhan khusus menengah ke bawah yang terdiri dari 15 orangtua di Sekolah Luar Biasa Tunas Harapan IV Sumobito. Hasil dari penelitian ini perekonomian orangtua anak berkebutuhan khusus mempengaruhi pendidikan anak berkebutuhan khusus.
\end{abstract}

\begin{abstract}
Abstarct
The economy of parents of children with special needs of middle and lower experienced difficulties in the domestic life of parents of children with special needs, it will be affected by their children. One aspect of children's needs that is impacted and seen is the aspect of children's education especially for the education of children with special needs. This study aims to determine the economic effect of parents of children with special needs of middle and lower classes on the education of children with special needs The methodology used is qualitative research with the subject of this research being parents of children with special needs of middle and lower consisting of 15 parents in Tunas Harapan IV Special School Sumobito. The results of this study the economy of parents of children with special needs affect the education of children with special needs.
\end{abstract}




\section{PENDAHULUAN}

Ekonomi merupakan salah satu kekuatan untuk berkembangnya suatu negara. Di Indonesia perkembangan ekonomi juga mengalami kemajuan yang sangat pesat dalam pelaksanaanya. Kemajuan perekonomian dapat di lihat dari segi bidang pendidikan, kesehatan, industri, pariwisata dan sebagainya. Dalam pelaksanaan ekonomi di bidang pendidikan sangat berpengaruh untuk kehidupan seseorang. Ekonomi adalah merupakan bidang yang memperbaiki kehidupan manusia. tingkat perekonomian masyarakat bisa digunakan untuk mengetahui tingkat taraf hidup hidup masyarakat tersebut menurut (Fitria, 2016). pada umumnya semakin tinggi tingkat perekonomian seseorang maka semakin mudah baginya untuk mengakses ke setiap seluk beluk aspek pendukung kehidupan manusia contoh aspek pendidikan. dengan perekonomian yang tinggi mereka akan mudah untuk menggapai pendidikan yang mereka inginkan, tetapi berbanding terbalik dengan yang berada dalam tingkat perekonomian rendah. dimana akan kesulitan menggapai pendidikan yang diinginkan bahkan mayoritas akan berlaku pasrah pada keadaan yang ada dan memperoleh pendidikan apa adanya. apalagi saat ini perekonomian dinegara kita Indonesia sedang tidak stabil dan mengakibatkan terjadinya ketimpangan perekonomian dalam masyarakat. sehingga menambah keterpurukan masyarakat pada perekonomian tingkat rendah. Pengaruh ekonomi terhadap pendidikan menurut (Dan et al., 2016) dalam penelitiannya mengatakan bahwa Pendidikan merupakan bagian yang tidak terpisahkan dari pembangunan nasional dan merupakan suatu unsur yang menentukan dalam pembangunan bangsa dan negara. Setiap tingkat dan jenis pendidikan diharapkan mampu mencapai fungsi pendidikan nasional dari berbagai aspek. Hurlock (2006:254) dalam (Orang et al., 2014) menyebutkan bahwa apabila status sosial ekonomi membaik, orang cenderung memperluas minat untuk mencakup hal-hal yang semula belum mampu dilaksanakannya. Dalam hal ini pendidikan mempunyai peranan yang penting dalam kehidupan masyarakat terlebih pada masyarakat perekonomian ke bawah.

Hal ini juga jamak dialami oleh para orangtua anak berkebutuhan khusus menengah ke bawah. Mayoritas adalah masyarakat dalam kelompok tingkat perekonomian rendah, yang pekerjaannya serabutan seperti buruh tani, buruh barang bekas, dsb. sehingga penghasasilannya pun tidak menentu dan berdampak pada perekonomian keluarga dan pemenuhan kebutuhan keluarga. Akhirnya hal tersebut mempengaruhi pola pikir para orangtua anak berkebutuhan khusus menengah ke bawah yang menganggap bahwa pendidikan bukanlah aspek yang sangat penting. Pola pikir masyarakat terhadap pendidikan menurut (Viii, 2005) pendidikan menjadi instrumen kekuatan sosial masyarakat untuk mengembangkan suatu sistem pembinaan anggota masyarakat yang relevan dengan tuntutan perubahan zaman. Menurut orangtua anak berkebutuhan khusus pendidikan hanya sebatas ijasah saja dan yang terpenting adalah anak berkebutuhan khusus hanya bisa bersekolah dan tidak memperhatikan pentingnya pendidikan bagi mereka. maka kepedulian orangtua terhadap pendidikan anak berkebutuhan khusus seakan hanya sebuah tatapan kosong, yang tidak bermakna. tanpa adanya imbal balik atau respon dari orangtua anak berkebutuhan khusus yang didasarkan pada 
perekonomian menengah ke bawah. Sedangkan Anak Berkebutuhan khusus juga harus mendapatkan hak-haknya sebagai seorang anak (Jauhari, 2018). salah satunya adalah pendidikan yang layak baik pendidikan formal, informal dan non formal agar anak dapat mandiri dan mempunyai kualitas. Hak-hak anak berkebutuhan khusus menurut (Abdullah, 2013) Anak-anak berkebutuhan khusus mempunyai kesetaraan dengan warga negara lainnya termasuk hak pendidikan. Kesetaraan hak mereka dengan warga negara lain ditegaskan dalam Pasal 31 Undang-Undang Dasar 1945, yang menyatakan bahwa "Tiap-tiap warga negara berhak mendapat pengajaran". Undang-Undang No. 20 Tahun 2003 tentang Sistem Pendidikan Nasional juga mengatur secara khusus perlindungan terhadap anak berkebutuhan khusus. Ditinjau dari Undang-undang No.20 Tahun 2003 bahwa anak berkebutuhan khusus membutuhkan pendidikan khusus dan layanan khusus bagi mereka.

Pendidikan anak berkebutuhan khusus adalah sarana untuk menyelenggarakan pendidikan bagi anak berkebutuhan khusus. pendidikan untuk anak berkebutuhan khusus juga diatur dalam UU N0. 20/2003 tentang Sisdiknas, Dalam Bab I, Pasal I, Ayat I yang berbunyi " pendidikan adalah usaha sadar dan terencana untuk mewujudkan suasana belajar dan proses pembelajaran agar peserta didik secara aktif mengembangkan potensi dirinya untuk memiliki kekuatan spiritual, keagamaan, pengendalian diri, kepribadian, kecerdasan akhlak mulia serta ketrampilan yang diperlukan dirinya, masyarakat, bangsa dan negara". Dengan merujuk pernyataan diatas bahwa pelayanan pendidikan yang disediakan oleh pemerintah disesuaikan dengan kebutuhan anak berkebutuhan khusus agar tercapai ketuntasan belajar yang tepat bagi anak berkebutuhan khusus. karena dengan pendidikan yang tepat anak berkebutuhan khusus akan mampu hidup mandiri dan siap menghadapi perkembangan kehidupan di masa yang akan datang. serta bisa dengan mudah beradaptasi menyesuaikan diri pada perkembangan zaman di era modern, perkembanagn zaman di era modern yang dimaksud adalah Anak berkebutuhan khusus dapat mengembangkan diri di bidang ilmu pengetahuan dan teknologi sehingga mereka bisa berkembang dan beradaptasi dilingkungan sekitar. Adapun klasifikasi anak berkebutuhan khusus menurut (Abdullah, 2013) anak yang dikategorikan berkebutuhan khusus dalam aspek fisik meliputi kelainan dalam indra penglihatan (tunanetra) kelainan indra pendengaran (tuna rungu) kelainan kemampuan berbicara (tuna wicara) dan kelainan fungsi anggota tubuh (tuna daksa). Anak yang memiliki kebutuhan dalam aspek mental meliputi anak yang memiliki kemampuan mental lebih (super normal) yang dikenal sebagai anak berbakat atau anak unggul dan yang memiliki kemampuan mental sangat rendah (abnormal) yang dikenal sebagai tuna grahita. Anak yang memiliki kelainan dalam aspek sosial adalah anak yang memiliki kesulitan dalam menyesuaikan perilakunya terhadap lingkungan sekitarnya. Anak yang termasuk dalam kelompok ini dikenal dengan sebutan tunalaras.

Dari permasalahan yang melatar belakangi dapat disimpulkan sebuah tujuan yang mendasari penelitian ini, yaitu pengaruh ekonomi orangtua anak berkebutuhan khusus terhadap pendidikan anak berkebutuhan khusus. Dan sering kali terjadi jika perekonomian orangtua anak berkebutuhan khusus menengah ke bawah mengalami kesulitan pada kehidupan rumah tangga orangtua anak 
berkebutuhan khusus, maka akan terimbas kepada anak mereka. Salah satu aspek kebutuhan anak yang terimbas dan terlihat jelas adalah aspek pendidikan anak terutama bagi pendidikan anak berkebutuhan khusus. Mayoritas dari orangtua anak berkebutuhan khusus lebih mengutamakan pendidikan bagi anak mereka yang normal karena menganggap pendidikan mereka lebih penting daripada anak mereka yang berkebutuhan khusus terkait dengan rendahnya taraf perekonomian keluarga. Sehingga kebutuhan pendidikan anak berkebutuhan khusus seakan tidak berguna dan sengaja diabaikan. Hal tersebut mengakibatkan anak berkebutuhan khusus harus merelakan pendidikannya baik itu secara formal, informal dan non formal terkondisi apa adanya. Dan Anak berkebutuhan khusus tidak pernah mengeluhkan kepada orangtua "kenapa mereka tidak diberi pelayanan yang baik oleh orangtua"

\section{METODE PENELITIAN}

Jenis penelitian yang digunakan adalah penelitian Deskriptif Kualitatif yang bertujuan untuk mengetahui seberapa besar pengaruh ekonomi orangtua anak berkebutuhan khusus menengah ke bawah terhadap pendidikan anak berkebutuhan khusus. Menurut (Wijayanti, 2010) Metode penelitian deskriptif kualitatif cenderung bersifat eklektik dan didasarkan oleh pendapat umum inkuiri naturalistik, dalam arti penelitian ini timbul karena kejadian atau fenomena yang dialamai sehari-hari. Sedangkan menurut (Wijayanti, 2010) Perspektif deskriptif kualitatif adalah perspektif dalam penelitian kualitatif yang tidak memiliki nama formal atau tidak memenuhi tipologi perspektif penelitian. Penelitian lebih menekankan penyebab yang melatarbelakangi orangtua anak berkebutuhan khusus, deskripsi pengalaman-pengalaman, serta deskripsi harapan, tujuan dan citacita. Kemudian penelitian bertujuan mengetahui aspirasi hidup orangtua anak berkebutuhan khusus, termasuk faktor yang mempengaruhi perekonomian orangtua anak berkebutuhan khusus terhadap pendidikan anak berkebutuhan khusus. Subjek penelitian dipilih berdasarkan kriteria tertentu sesuai dengan masalah dan tujuan penelitian Subyek penelitian ini adalah 15 orangtua anak berkebutuhan khusus menengah ke bawah di Sekolah Luas Biasa Tunas Harapan IV Sumobito.

Metode yang digunakan dalam pengumpulan data mengenai pengaruh Ekonomi orangtua anak berkebutuhan khusus terhadap pendidikan anak berkebutuhan khusus adalah media angket dan wawancara. Media angket menurut (Puspasari, 2018) Secara umum, ada dua jenis kuesioner yaitu kuesioner tertutup dan terbuka. Kuesioner tertutup adalah kuesioner yang telah disediakan alternatif jawabannya sehingga responden tinggal memilih yang sesuai dengan keadaan dirinya. Sedangkan kuesioner terbuka adalah kuesioner yang jawabannya belum disediakan sehingga responden bebas menuliskan apa yang dia rasakan. Ada beberapa maksud dan tujuan kenapa kuisionar dipergunakan dalam pengumpulan data yaitu kuesioner memudahkan sumber data dalam memberikan jawaban serta kepraktisan serta penggunaanya. Penggunaan angket merupakan teknik pengumpulan data secara tidak langsung. Bentuk pertanyaan dapat bersifat terbuka, terstruktur, atau tertutup. Hal-hal yang perlu diperhatikan dalam penyusunan angket antara lain: kembangkan petunjuk 
pengisian/pengantar yang di dalamnya berisi maksud, jaminan kerahasiaan jawaban, dan ucapan terima kasih serta butir pertanyaan dirumuskan secara jelas dengan menggunakan bahasa populer dan untuk pertanyaan terbuka sediakan tempat untuk menuliskan komentar responden.

Wawancara atau interview menurut (Puspasari, 2018) merupakan salah satu teknik pengumpulan data yang juga menggunakan instrumen non tes yakni berupa pedoman wawancara. Pedoman wawancara dipergunakan sebagai panduan untuk mendapatkan informasi tertentu tentang keadaan responden dengan jalan tanya-jawab sepihak. Dikatakan sepihak karena pertanyaanpertanyaan yang diajukan dalam kegiatan wawancara itu hanya berasal dari pihak pewawancara saja, sementara responden hanya bertugas sebagai penjawab. Ada banyak pembagian wawancara yang dilakukan para ahli. salah satu diantaranya adalah membagi wawancara kedalam dua bentuk yaitu wawancara bebas dan wawancara terpimpin. Yang dimaksud wawancara terpimpin adalah suatu kegiatan wawancara yang pertanyaan-pertanyaan serta kemungkinan-kemungkinan jawabannya itu telah dipersiapkan pihak pewawancara, responden tinggal memilih jawaban yang sudah dipersiapkan pewawancara. Sebaliknya dalam wawancara bebas, responden diberi kebebasan untuk menjawab pertanyaan-pertanyaan pewawancara sesuai dengan pendapatnya tanpa terikat oleh ketentuanketentuan yang telah dibuat pewawancaranya.

Untuk menentukan hasil dari angket dan wawancara peneliti menggunakan media angket dan hasil wawancara terhadap 15 orangtua anak berkebutuhan khusus menengah ke bawah di Sekolah Luar Biasa Tunas Harapan IV Sumobito. Angket atau kuisioner diberikan kepada 15 orangtua anak berkebutuhan khusus di Sekolah Luar Biasa Tunas Harapan IV Sumobito. Wawancara dilakukan kepada 15 orangtua anak berkebutuhan khusus menengah ke bawah di Sekolah Luar Biasa Tunas Harapan IV Sumobito dengan memberikan 10 pertanyaan yang berhubungan dengan pengaruh ekonomi orangtua anak berkebutuhan khusus menengah ke bawah terhadap pendidikan anak berkebutuhan khusus, sebagai salah satu bukti atau hasil dari penelitian ini

\section{HASIL DAN PEMBAHASAN}

Orangtua adalah orang yang mengasuh, menjaga, menyayangi, mendidik dan melindungi anak dari kecil sampai dewasa. Orangtua bertugas menyayangi dan memberikan perlindungan terhadap anak. Dalam mengasuh anak berkebutuhan khusus orangtua mempunyai pengaruh yang besar terhadap anak, agar mereka bisa hidup mandiri selain itu orangtua juga wajib mendampingi, membimbing, serta memberikan hak-hak yang layak bagi anak berkebutuhan khusus. Banyak orangtua anak berkebutuhan khusus yang bergantung pada orang lain dan menganggap bahwa anak berkebutuhan khusus tidak bisa menjadi kebanggaan tersendiri bagi orangtua. Anak berkebutuhan khusus juga mempunyai hak-hak yang layak sebagai seorang anak. Hak-hak anak berkebutuhan khusus antara lain adalah hak diberi kasih sayang, hak dilindungi, hak diperlakukan yang sama dengan anak normal lainnya, hak diberikan pengajaran yang sama dengan anak normal lainnya, dalam arti orangtua berperan penting dalam pemenuhan hak-hak anak berkebutuhan khusus karena orangtua 
wajib untuk memenuhi hak-hak anaknya yang berkebutuhan khusus. Menurut Heward (2003) dalam(Vani et al., 2015) menyatakan bahwa efektivitas berbagai program penanganan arti efektivitas sendiri adalah suatu pencapaian tujuan yang diambil secara tepat dan akurat, dalam arti sebagai orangtua harus memiliki suatu pencapaian tujuan secara tepat dalam penanganan bagi anaknya yang berkebutuhan khusus, orangtua memberikan penanganan secara tepat seperti pelayanan pendidikan yang maksimal bagi anak berkebutuhan khusus dan peningkatan kemampuan hidup anak berkebutuhan khusus akan sangat ditentukan oleh peran serta dan dukungan penuh dari orangtua sebab orangtua adalah pihak yang mengenal dan memahami berbagai aspek dalam diri seseorang dengan jauh lebih baik daripada orang-orang yang lain. Hak-hak anak berkebutuhan khusus diantara lain adalah mendapatkan pendidikan yang layak bagi mereka selain pendidikan ABK juga berhak mendapatkan perlindungan dan kasih sayang dari orangtua. Untuk mengukur pengaruh faktor ekonomi orang tua terhadap pendidikan anak berkebutuhan khusus maka penelitian ini difokuskan pada pengaruh ekonomi orangtua menegah kebawah terhadap pendidikan anak berkebutuhan khusus. Dengan subyek 15 orangtua ABK di SLB Tunas Harapan IV Sumobito. Hasil angket dan wawancara kepada orangtua dengan menggunakan 5 indikator mengenai pengaruh ekonomi orangtua terhadap pendidikan anak berkebutuhan khusus dapat di deskripsikan sebagai berikut.

1. Pekerjaan orangtua yang tidak tetap dan penghasilan di bawah rata-rata UMR Kabupaten Jombang.

Komponen pertama yang ditelaah adalah pekerjaan orangtua anak berkebutuhan khusus. Hasil analisis data, secara garis besar, disajikan pada Tabel 1.

Tabel 1: Hasil Analisis pekerjaan orangtua yang tidak tetap dan penghasilan dibawah rata-rata UMR Kabupaten Jombang.

Pertanyaan

Jawaban

\begin{tabular}{lll}
\cline { 2 - 3 } & Ya & Tidak \\
\hline $\begin{array}{l}\text { Apakah pekerjaan orang tua tidak tetap dan penghasilan } \\
\text { dibawah rata-rata UMR Kab. Jombang }\end{array}$ & 15 0rang & - \\
\hline
\end{tabular}

Berdasarkan Tabel 1, dapat digarisbawahi bahwa hasil angket menunjukkan bahwa pekerjaan orangtua anak berkebutuhan khusus tidak tetap dan penghasilan dibawah rata-rata UMR Kab. Jombang. Dari hasil wawancara dengan orangtua ABK bahwa pekerjaan orangtua tidak tetap dan penghasilan dibawah rata-rata UMR Kab. Jombang. Menurut (Puspitasari, 2018) UMR kabupaten Jombang pada tahun 2018 berkisar Rp. 2.264 .135 per bulan. sedangkan penghasilan orangtua anak berkebutuhan khusus dibawah rata-rata UMR. Penghasilan rata-rata orangtua Rp. 1.000 .000 s/d Rp 1.500 .000 perbulan. dengan penghasilan dibawah rata-rata UMR 
kabupaten Jombang perbulannya, para orangtua mengatakan penghasilan itu kurang cukup untuk memenuhi kebutuhan hidup sehari-hari.

2. Anggota keluarga lebih dari 4 orang dan penghasilan tidak mencukupi untuk memenuhi kebutuhan baik kebutuhan primer dan sekunder.

Komponen kedua yang ditelaah adalah anggota keluarga dan pemenuhan kebutuhan primer dan sekunder. Hasil analisis data, secara garis besar, disajikan pada Tabel 2.

Tabel 2. Hasil Analisis anggota keluarga lebih dari 4 orang dan penghasilan tidak mencukupi untuk memenuhi kebutuhan baik kebutuhan primer dan sekunder.

\begin{tabular}{lcc}
\multicolumn{1}{c}{ Pertanyaan } & \multicolumn{2}{c}{ Jawaban } \\
\cline { 2 - 2 } & Ya & Tidak \\
\hline $\begin{array}{l}\text { Anggota keluarga lebih dari 4 orang dan penghasilan tidak } \\
\text { mencukupi untuk memenuhi kebutuhan primer dan sekunder }\end{array}$ & 15 0rang & - \\
\hline
\end{tabular}

Berdasarkan Tabel 2, dapat digarisbawahi bahwa anggota keluarga lebih dari 4 orang dan penghasilan tidak mencukupi untuk kebutuhan primer dan sekunder. Dari hasil wawancara dengan orangtua ABK bahwa anggota keluarga mereka lebih dari 4 orang dan dengan minimnya penghasilan yang didapat perbulan tidak mencukupi kebutuhan primer maupun sekunder. Salah satu kebutuhan sekunder yang tidak bisa dipenuhi oleh orangtua adalah kendaraan bermotor. Kendaraan bermotor sebagai alat transportasi orangtua untuk mengantarkan anaknya berangkat dan menjemput di sekolah. Banyak ABK yang terhambat untuk pergi kesekolah karena tidak adanya kendaraan bermotor.

3. Pendidikan Orangtua Yang Ditempuh Jenjang SD-SMP

Komponen ketiga yang ditelaah adalah Pendidikan orangtua. Hasil analisis data, secara garis besar, disajikan pada Tabel 3 .

Tabel 3: Hasil Analisis pendidikan orangtua yang ditempuh jenjang SD-SMP.

\begin{tabular}{|c|c|c|}
\hline \multirow[t]{2}{*}{ Pertanyaan } & \multicolumn{2}{|l|}{ Jawaban } \\
\hline & $\mathrm{Ya}$ & Tidak \\
\hline Pendidikan yang ditempuh jenjang SD atau SMP saja & 15 0rang & - \\
\hline
\end{tabular}

Berdasarkan Tabel 3, dapat digarisbawahi bahwa pendidikan orangtua yang ditempuh ditingkat SD atau SMP saja. Dari hasil wawancara dengan orangtua ABK bahwa Pendidikan mereka hanya sebatas jenjang SD atau SMP saja. sehingga dengan pendidikan yang minim maka akan mempengaruhi pola pikir orangtua terhadap pendidikan bagi anak terutama pendidikan bagi ABK. Menurut(Tulangow et al., 2013) Seseorang yang memiliki pendidikan tinggi diasumsikan memiliki pengetahuan yang baik, dalam arti orangtua yang memiliki pengetahuan 
yang baik, mereka akan memberikan pendidikan yang baik pula bagi anak mereka yang berkebutuhan khusus.

4. Orangtua Memberikan Pelayanan Yang Baik Bagi ABK

Komponen keempat yang ditelaah adalah orangtua memberikan pelayanan yang baik bagi ABK. Hasil analisis data, secara garis besar, disajikan pada Tabel 4.

Tabel 4: Orangtua memberikan pelayanan yang baik bagi ABK.

Pertanyaan

Jawaban

\begin{tabular}{lll} 
& Ya & Tidak \\
\cline { 2 - 3 } & & \\
\hline $\begin{array}{l}\text { Orangtua memberikan pelayanan yang baik pada anak, seperti } \\
\text { menunjang kebutuhan, memfasilitasi, pendidikan yang layak } \\
\text { pada ABK }\end{array}$ & & \\
\hline
\end{tabular}

Berdasarkan Tabel 4, dapat digarisbawahi bahwa orangtua setuju untuk memberikan pelayanan yang baik bagi ABK. Dari hasil wawancara dengan orangtua ABK bahwa Orangtua memberikan pelayanan yang baik bagi $\mathrm{ABK}$ seperti memberikan pelayanan, fasilitas dan pendidikan bagi anaknya namun orang tua mengatakan pelayanan dan fasilitas apa yang harus diperuntukkan bagi ABK tersebut karena orangtua tidak memahami pelayanan dan fasilitas yang tepat bagi ABK. Menurut (Tua et al., 2013) anak berkebutuhan khusus mendapatkan pelayanan yang tepat, khususnya keterampilan hidup (life skill) sesuai minat dan potensinya, maka anak akan lebih mandiri. Namun, jika tidak ditangani secara tepat, maka perkembangan kemampuan anak mengalami hambatan dan menjadi beban orangtua, keluarga, masyarakat dan negara.

5. Hak-Hak Anak Berkebutuhan Khusus

Komponen kelima yang ditelaah adalah Hak-hak anak berkebutuhan khusus. Hasil analisis data, secara garis besar, disajikan pada Tabel 5 .

Tabel 5: Hak-hak Anak berkebutuhan khusus.

Pertanyaan Jawaban

\begin{tabular}{lll}
\cline { 2 - 3 } & Ya & Tidak \\
\hline $\begin{array}{l}\text { Apakah orangtua mengetahui, apa saja hak-hak } \\
\text { anak berkebutuhan khusus. }\end{array}$ & - & 15 0rang \\
\hline
\end{tabular}

Berdasarkan Tabel 5, dapat digarisbawahi bahwa orangtua tidak mengetahui hak-hak bagi ABK. Dari hasil wawancara dengan orangtua ABK bahwa Orangtua tidak mengetahui hak-hak bagi ABK, yang mereka tahu hak untuk anak hanyalah bersekolah saja. Karena minimnya pendidikan orangtua mengakibatkan mereka tidak mengetahui pengertian dari hak itu sendiri. 
Pengertian hak Menurut (Inklusi, 2014) adalah kesetaraan dengan warga negara lainnya termasuk hak pendidikan. Dapat disimpulkan bahwa setiap anak berkebutuhan khusus mempunyai hak yang sama dengan anak normal lainnya. Seperti hak mendapatkan pendidikan, hak diberi kasih sayang dan hak dilindungi oleh orangtua.

Berdasarkan Dari lembar angket dan wawancara, diketahui bahwa pekerjaan 15 orangtua ABK tidak tetap dan penghasilan dibawah rata-rata UMR. Selain itu jumlah anggota keluarga rata-rata dari 15 orangtua $\mathrm{ABK}$ lebih dari 4 anggota keluarga yang tinggal dalam satu atap. Dengan bertambah banyaknya jumlah anggota keluarga maka bertambah pula jumlah pengeluaran setiap bulannya. Selain itu karena minimnya penghasilan yang didapat, banyak orangtua yang tidak mampu untuk memenuhi kebutuhan sekunder seperti membeli kendaraan bermotor. Dengan tidak adanya kendaraan bermotor maka banyak dari anak-anak berkebutuhan khusus yang tidak bersekolah dan jarak tempuh untuk ke sekolah jauh sekitar 5 s/d 10 kilometer. Dalam kurun waktu 1 bulan terkadang anak hanya disekolahkan selama 10 hari, untuk 20 hari anak tidak disekolahkan dan dibiarkan dirumah. Padahal jika dilihat dari segi tanggungjawab Orangtua bertugas untuk memberikan pelayanan yang tepat kepada anak berkebutuhan khusus. Menurut (Tua et al., 2013) anak berkebutuhan khusus mendapatkan pelayanan yang tepat, khususnya keterampilan hidup (life skill) sesuai minat dan potensinya, maka anak akan lebih mandiri. Namun, jika tidak ditangani secara tepat, maka perkembangan kemampuan anak mengalami hambatan dan menjadi beban orangtua, keluarga, masyarakat dan negara. Orangtua dirumah sebagai pemberi pelayanan dan penanganan yang baik kepada anaknya. namun pada umumnya orangtua masih kurang mempunyai kesadaran dan tanggung jawab untuk memberikan pelayanan yang tepat, persamaan hak dan kesempatan bagi anak-anak berkebutuhan khusus. Hal ini dikarenakan kurangnya pengetahuan orangtua dan perekonomian keluarga sehingga orangtua tidak mengetahui tentang bagaimana merawat, mendidik, mengasuh dan memenuhi kebutuhan anak-anak berkebutuhan khusus. Orangtua merupakan faktor terpenting dalam memfasilitasi tumbuh kembang dan perlindungan anak berkebutuhan khusus terutama dalam pendidikan anak berkebutuhan khusus

\section{KESIMPULAN}

Berdasarkan dari hasil penelitian serta pembahasan tentang pengaruh ekonomi orangtua anak berkebutuhan khusus menengah ke bawah terhadap pendidikan anak berkebutuhan khusus di Sekolah Luar Biasa Tunas Harapan IV Sumobito dapat ditarik kesimpulan bahwa perekonomian orangtua anak berkebutuhan khusus menengah ke bawah mempengaruhi pendidikan anak berkebutuhan khusus 


\section{DAFTAR PUSTAKA}

(Fitria, 2016)Abdullah, N. (2013). Mengenal anak berkebutuhan khusus. 86, 1-10.

Dan, T. U. A., Efficacy, S., Minat, T., \& Studi, M. (2016). Economic Education Analysis Journal. 5(3), 1034-1045.

Fitria, T. N. (2016). Kontribusi Ekonomi Islam Dalam Pembangunan Ekonomi Nasional. Jurnal Ilmiah Ekonomi Islam, 2(03), 29-40. https://doi.org/10.29040/jiei.v2i03.3

Inklusi, D. I. S. (2014). Pemenuhan hak anak berkebutuhan khusus di sekolah inklusi. 176-186.

Jauhari, M. N. (2018). Keterlibatan Orangtua dalam Penanganan Anak Berkebutuhan Khusus. Jurnal Abadimas Adi Buana, 2(1), 55-64.

Orang, E., Dan, T. U. A., Sekolah, L., Siswa, P., Xii, K., Smk, A., \& Kendal, N. (2014). Economic Education Analysis Journal. 3(1), 152-159.

Puspasari, D. E. K. A. (2018). Pengembangan Media Magic Drawer.

Puspitasari, V. Y. (2018). Implementasi Peraturan Gubernur Nomor 52 Tahun 2016 Tentang Tata Cara Penetapan Upah Minimum Provinsi, Upah Minimum Kabupaten/Kota Dan Upah Minimum Sektoral Kabupaten/Kota Serta Penangguhan Upah Minimum Kabupaten/Kota Di Jawa Timur (Studi diKabupaten Jomb. 1-7.

Tua, O., Masyarakat, D. A. N., \& Winarsih, D. S. (2013). Anak Berkebutuhan Khusus Bagi Pendamping.

Tulangow, J. T., Mariati, N. W., \& Mintjelungan, C. (2013). Gambaran Status Karies Murid Sekolah Dasar Negeri 48 Manado Berdasarkan Status Sosial Ekonomi Orang Tua. E-GIGI, 1(2), 8593. https://doi.org/10.35790/eg.1.2.2013.2621

Vani, G. C., Raharjo, S. T., \& Hidayat, E. N. (2015). Pengasuhan (Good Parenting) Bagi Anak Dengan

Disabilitas. Prosiding Penelitian Dan Pengabdian Kepada Masyarakat, 2(1), 96-102. https://doi.org/10.24198/jppm.v2i1.13263

Viii, B. (2005). Pendidikan Dan Perubahan Sosial-Budaya. 63-93.

Wijayanti, P. (2010). The aspiration of street children life is semarang. 1-30.

UU N0. 20/2003 tentang Sisdiknas, Dalam Bab I, Pasal I, Ayat 1 